\title{
CITRAAN PSIKOPAT PADA TOKOH UTAMA DALAM NASKAH DRAMA “CERMIN" KARYA NANO RIANTIARNO
}

\author{
Mohammad Khikam Zahidi', Hidayah Budi Qur'ani \\ Fakultas Keguruan dan Ilmu Pendidikan, Universitas Muhammadiyah Malang \\ I'ikhalzahidi@webmail.umm.ac.id, ${ }^{2}$ qurani@umm.ac.id
}

\begin{abstract}
Abstrak
Tingkat kriminalitas di Indonesia beberapa tahun terakhir menunjukkan peningkatan yang begitu memprihatinkan, serta pada beberapa kasus dikaitkan dengan gangguan gejala psikopat. Psikopat ialah bentuk kekalutan mental yang ditandai dengan tidak adanya pengorganisasian dan pengintegrasian pribadi, tidak bisa bertanggung jawab secara moral, selalu konflik dengan norma sosial dan hukum yang diciptakkan oleh angan-angannya sendiri. Penelitian ini bertujuan untuk mendeskripsikan fenomena perilaku psikopat pada naskah drama "CERMIN" karya Nano Riantiarno dengan pendekatan psikologi sastra, khususnya menggunakan teori gangguan kepribadian psikopat Sigmund Freud. Pada dasarnya psikologi sastra memberikan perhatian pada masalah kejiwaan para tokoh fiksional yang terkandung dalam karya sastra. Sasaran dalam penelitian ini adalah fenomena perilaku psikopat yang dialami oleh tokoh dengan mengkaji bentuk perilaku, dan faktor penyebabnya. Teknik analisis data yang digunakan adalah teknik deskriptif kualitatif. Berdasarkan hasil penelitian dapat diketahui bahwa (1) bentuk perilaku psikopat tokoh dalam naskah drama "CERMIN" karya Nano Riantiarno diketahui berdasarkan ciri perilaku khusus pada psikopat yaitu berperilaku antisoasial, suka memanipulasi, berperilaku sadistis, sehingga dapat ditentukan bentuk perilaku psikopa yang dialami. (2) Faktor yang menyebabkan tokoh dalam naskah drama "CERMIN" karya Nano Riantiarno berperilaku psikopat yaitu faktor biologis dan faktor lingkungan.
\end{abstract}

Kata Kunci: Psikopat, Psikopat Fenomena Perilaku, Psikologi Sastra.

\begin{abstract}
The level of crime in Indonesia in recent years shows a very alarming increase, and in some cases is associated with disorders of psychopathic symptoms. Psychopath is a form of mental confusion characterized by lack of personal organization and integration, being morally irresponsible, always in conflict with social and legal norms created by his own imagination. This study aims to describe the phenomenon of psychopathic behavior in the drama script "CERMIN" by Nano Riantiarno with a literary psychology approach, specifically using the theory of psychopathic personality disorder Sigmund Freud. Basically, psychology of literature pays attention to the mental problems of fictional figures contained in literary works. The target in this study is the phenomenon of psychopathic behavior experienced by figures by examining the form of behavior, and its causal factors. The data analysis technique used is descriptive qualitative technique. Based on the results of this research, it can be seen that (1) the form of psychopathic behavior of the characters in the drama script "CERMIN" by Nano Riantiarno is known based on the specific behavioral traits of psychopaths that are antisoasial behavior, likes to manipulate, sadistic behavior, so that it can be determined the form of psychopathic behavior experienced. (2) Factors that cause characters in the drama script "CERMIN" by Nano Riantiarno behave psychopathically namely biological factors and environmental factors.
\end{abstract}

Keywords: Psychopaths, Psychopathic Behavior Phenomena, Literary Psychology 


\section{PENDAHULUAN}

Dalam kehidupan manusia banyak terjadi fenomena-fenomena sosial terutama dalam hal kejiwaan dan kejahatan yang mewarnai perjalanan hidup manusia. Perilaku tersebut terjadi karena adanya ketidakseimbangan kondisi sosial di dalam realitas kehidupan. Hal tersebut, dapat memicu ketidaksesuaian realitas yang menimbulkan rasa ketidakpuasan. Kondisi sosial masyarakat diwujudkan dalam karya sastra. Karya sastra memiliki hubungan antara manusia dengan keadaan sosial yang menjadi inspirasi pengarang dalam realitas kehidupan. Sastra merupakan kata serapan dari Bahasa Sansekerta yang artinya adalah "tulisan yang mengandung instruksi atau pedoman". Dalam penggunaannya, kata ini lebih sering digunakan untuk merujuk pada kesusasteraan, yaitu hasil karya penulisan yang mengandung keindahan dan unsur seni, misalnya puisi, drama dan esai. Di sisi lain, psikologi sendiri merupakan sebuah cabang ilmu pengetahuan yang mempelajari tingkah laku dan proses mental yang dialami dan diperbuat oleh manusia.

Kajian sastra yang memandang karya sebagai aktivitas kejiwaan. Pengarang akan menggunakan cipta, rasa, dan karya dalam berkarya. Karya sastra yang dipandang sebagai fenomena psikologis, akan menampilkan aspek-aspek kejiwaan melalui tokohtokoh jika kebetulan teks berupa drama maupun prosa. Berbicara mengenai kejiawaa seseorang karya sastra sendiri memiliki peranan mengenai hal tersebut yaitu seperti halnya psikologi sastra dimana psikologi sastra itu sendiri adalah ilmu yang memepelajari kejiawaan setiap seseorang (Andalas, 2017: 123-134).

Dalam hal kejiwan sastra juga digunakan sebagai cermin dari kepribadian seseorang karena karya sastra baik berupa naskah sebuah drama, maupun puisi sangatlah memengaruhi karakter si pembaca karena dalam karya sastra itu sendiri terkandung unsur-unsur tertentu atau unsur moral yang mengajak untuk mengintropeksi diri bagi sang pembaca karya sastra (Zahidi, 2019: 697-702).

Analisis psikologi satra sendiri juga banya memiliki berbagai cabang antara lain yaitu cabang ilmu psikopat ilmu psikopat itu sendi termasuk dalam psikologi sastra karena pada dasarnya psikologi memperhatikan mengenai masalah kejiwaan yang dialami oleh para tokoh fiksional yang terkandung dalam sebuah karya sastra (Rozali, 2018). Fenomena perilaku psikopat yang terjadi di masyarakat secara tak sadar telah mengilhami berbagai bentuk karya seni salah satunya karya sastra. Hal itu terjadi karena karya sastra tak lepas dari pengarang yang menciptakanya. Fenomena perilaku psikopat itu oleh pengarang dituangkan berdasarkan pengalamannya yang berkaitan dengan psikopat atau imajinasi pengarang yang mampu menggambarkan tokoh seorang psikopat. Psikopat secara etimologis merupakan gabungan kata dari bahasa Yunani yaitu psyche dan pathos yang berarti penyakit jiwa. Psikopat berbeda dengan gila (psikosis), karena seorang psikopat sadar sepenuhnya atas perbuatannya. Gejala psikopat sendiri disebut dengan psikopati.

Dari sekian banyak karya sastra yang menampilkan fenomena perilaku psikopat, penelitian ini menggunakan naskah yang berjudul "Cermin" karya Nano Riarntiarno sebagai objek penelitian. Naskah ini mengangkat sebuah kisah psyhcology thriller dengan psikopat sebagai persoalan utamanya. Naskah ini secara jelas menampilkan fenomena perilaku psikopat berupa siksaan, kekerasan, bahkan pembunuhan yang dilakukan oleh tokoh yang ada di dalam naskah tersebut

Dalam naskah drama yang berjudul "Cermin" karya Nano Riantiarno menceritakan sebuah tokoh yang mengalami perubahan di dalam jiwanya setelah menikah dengan istrinya yang seorang pelacur sehingga mengakibatkan seorang tokoh 
laki-laki itu berani membunuh orang 6 orang dan melukai 3 orang, layaknya seorang pembunuh profesional, tetapi hal itu tidak dibayangkan oleh seorang laki-laki tersebut yang tidak memiliki kemampuan dan tidak berani mengakhiri hidup seseorang.

Beberapa penelitian telah mengkaji mengenai perilaku psikopat (Rozali, 2018) dalam artikel ilmiahnya yang berjudul "Fenomena Perilaku Psikopat dalam Novel Katarsis Karya Anastasia Aemilia: Kajian Psikologi Sastra" hasil penelitian ini diketahui bahwa (1) bentuk perilaku psikopat tokoh dalam novel Katarsis karya Anastasia Aemilia diketahui berdasarkan ciri perilaku khusus pada psikopat yaitu berperilaku antisoasial, suka memanipulasi, berperilaku agresif, berperilaku sadistis, serta tidak menyesal dan tidak merasa bersalah sehingga dapat ditentukan bentuk perilaku psikopat yang terbagi ke dalam tiga bentuk, yaitu ringan, sedang, dan berat. (2) Faktor yang menyebabkan tokoh dalam novel Katarsis berperilaku psikopat yaitu faktor biologis dan faktor lingkungan.

Selain itu, penelitian yang dilakukan oleh (Fathoni dan Imam, 2020) dalam skripsinya yang berjudul "Analisis Tokoh Khamid dalam Naskah Pasung Karya Dwi Mustanto (Analisis Teori Psikoanalisa" hasil penelitiannya diketahui 1) Id yang muncul pada tokoh Khamid lebih kepada instink (naluri) seperti bagaimana ia merindukan masa-masa indah ketika ia kecil sebelum ia dipasung, 2) Ego yang ada pada naskah yaitu Ego pada ayah Khamid ditunjukkan dengan bagaimana ia menahan putranya (Khamid) tanpa memperhatikan keinginan sebenarnya dari anaknya, 3) Superego yang muncul pada tokoh Khamid adalah ketika Khamid lebih memilih untuk merelakan temannya pergi daripada menemaninya. Bentuk konseling dalam naskah asung terdapat teknik asosiasi bebas dan analisis transferensi.

Sementara penelitian yang dilakukan oleh (Anwar, 2018) yang berjudul "Kritik Sosial dalam Naskah Drama Alangkah Lucunya Negeri Ini Karya Deddy Mizwar" hasil penelitiannya diketahui untuk menganalisis bentuk-bentuk kritik sosial dalam naskah drama alangkah lucunya negeri ini, hasil penelitian adalah sebagai berikut: (1) kemiskinan, (2) kejahatan, (3) Disorganisasi keluarga, (4) pendidikan, (5) lingkungan hidup, (6) birokrasi, (7) agama dan keperyaan.

Penelitian ini memiliki peranan penting yang akan mengungkap fenomena perilaku psikopat berdasarkan tokoh yang terdapat pada naskah drama dengan teori psikologi sastra, khususnya teori psikopat menurut Sigmund Freud. Perbedaan lainnya, penelitian ini akan membahas bentuk perilaku psikopat, serta faktor yang menyebabkan tokoh dalam naskah mengalami gangguan kepribadian psikopat.

\section{METODE PENELITIAN}

Penelitian ini merupakan penelitian kualitatif. Mulyadi (2011) menyatakan bahwa "Penelitian kualitatif ini lebih menekankan pada penggunaan diri si peneliti sebagai instrumen, peneliti harus dapat diterima oleh informan dan lingkungannya agar mampu mengungkap semua data yang tersembunyi melalui bahasa tutur, bahasa tubuh, perilaku maupun ungkapan-ungkapan yang berkembang dalam dunia dan lingkungan informan".

Sumber data penelitian ini dari naskah drama berjudul "CERMIN" karya Nano Riantiarno (1977). Data yang digunakan untuk penelitian yaitu berupa prolog dan dialog antara pemain dalam naskah. Prolog dan dialog antartokoh tersebutlah yang akan menggambarkan adanya perilaku psikopat yang terdapat dalam naskah drama berjudul "CERMIN" karya Nano Riantiarno. 
Teknik pengumpulan data menggunakan teknik simak dan catat. Teknik simak dan catat merupakan teknik yang menuntut peneliti untuk menyimak naskah drama untuk mendapatkan data. Pertama, naskah drama "CERMIN" karya Nano Riantiarno dibaca secara berulang-ulang. Kedua, isi naskah drama dianalisis dan ditandai yang mengacu pada rumusan masalah yang ditentukan yaitu sikap psikopat yang dialami oleh tokoh.

Penelitian ini juga menggunakan uji validasi data. Ghozali (2016) menyatakan bahwa "Uji validasi dilakukan untuk mengukur sah atau valid tidaknya suatu kuesioner. Penelitian ini menggunakan teknik validasi data berupa trianggulasi teori". Peneliti menggunakan sudut pandang lebih dari satu teori untuk membahas persoalan sikap psikopat dalam naskah drama CERMIN Teori tersebut adalah teori psikopat oleh Sigmund Freud.

\section{HASIL DAN PEMBAHASAN}

Penelitian terhadap naskah drama ini menggunakan teori psikologi sastra, secara lebih khusus menggunakan teori gangguan kepribadian Sigmund Freud. Pertama, peneliti menganalisis bentuk dari perilaku psikopat yaitu perilaku psikopat tokoh berdasarkan pada ciri-ciri. Kedua, peneliti menganalisis faktor yang menyebabkan tokoh dalam nasakah yang berperilaku psikopat.

\section{Bentuk Perilaku Psikopat Tokoh Utama Dalam Naskah Darama Cermin Karya Nano Riantiarno}

Untuk membuktikan bahwa tokoh dalam naskah drama "Cermin" yang berperilaku psikopat, selanjutnya peneliti menganalisis perilaku tokoh berdasarkan ciriciri psikopat sehingga dapat menentukan bentuk perilaku pada tokoh utama dalam naskah drama Cermin.

Berdasarkan ciri-ciri psikopat yang telah disebutkan pada landasan teoretis, peneliti menggolongkan ciri-ciri tersebut ke dalam beberapa perilaku psikopat, karena ciri-ciri psikopat tersebut membangun perilaku khusus yang dilakukan oleh seorang psikopat. Perilaku khusus itu antara lain; (1) berperilaku antisosial, (2) suka memanipulasi, (3) berperilaku sadis.

\section{Berperilaku Antisoial}

Perilaku antisosial pada seorang psikopat terjadi karena kurangnya kemampuan memproses informasi secara emosional, dan kurangnya kemampuan dalam memahami orang lain (Santoso dkk., 2017: 18-27). Seperti pada kutipan di bawah ini.

"Sampai mati...... Su! Su! Sunni! Kenapa jadi begini? Kenapa kau pergi? Kenapa aku ada di sini? Kenapa mesti ada hal-hal yang mendorong kita melakukan hal-hal? Kenapa kamu tidak mau menurut? Kenapa waktu kamu masih ada, rasanya semua terang dan jelas. Tanpa kabut. Tiap kupandangi diriku di kaca, maka kulihat ujud seorang laki-laki yang utuh. Lalu sekarang, kau entah ada di mana? Jarak dan tembok memisahkan kita. Semua yang terlihat jadi samara-samar. Bukan maksudku melakukan itu. Terjadi begitu saja, didorong oleh kekuatan yang ajaib! Seperti alir sungai yang dibendung, makin tinggi bendungannya makin banyak air yang tertampung dan tekanan untuk molos mencari aliran lain makin besar" (Riantiarno, 1977). 
Perilaku antisosial pada naskah drama Cermin terjadi pada tokoh utama yaitu, ketika tidak menunjukan kepedulian terhadap lingkungan sekitar, berperilaku acuh terhadap keluarganya, tidak menunjukkan tanggung jawabnya terhadap anaknya, dan lebih mementingkan dirinya sendiri, tanpa berpikir bagaimana perasaan yang dialami.

\section{Suka Memanipulasi}

Perilaku suka memanipulasi merupakan ciri yang sering dilakukan oleh seorang psikopat untuk melancarkan atau menutupi aksi kejahatannya. Dalam pelaksanannya, bentuk perilaku suka memanipulasi ini dilakukan oleh psikopat dengan cara berbohong, menipu, dan berbicara sendiri. Seperti kutipan di bawah ini.

"Kita ngobrol-ngobrol, untuk mengisi waktu. Obrolan yang intim bisa menambah rasa kekawanan. Tidak usah dijawab. Aku yakin pasti kau mau. Ya, kita akan ngobrol-ngobrol. Aku dapat pertama, kamu yang kedua. Akan kubeberkan semuanya tanpa malu-malu. Tapi musti janji, begitu aku selesai kau segera menyambungnya. Dengan begitu tak akan terasa lagi waktu lewat. Pagi-pagi sekali kita akan berpelukan mengucapkan salam perpisahan, barangkali sambil tertawa-tawa atau barangkali kita akan saling menangisi. Entahlah! Jangan menjawab, aku tahu kau sama seperti aku, termasuk orangorang yang selalu berusaha untuk menepati janji. Dengan adanya kau di situ, meskipun kau tidak menyapa apa-apa bisa kupastikan kita akan selalu bersama-sama, setia sampai mati" (Riantiarno, 1977).

Dari kutipan di atas seorang tokoh sedang memanipulasi atau merekayasa interaksi sosial dengan cermin sebagai benda hidup dan ingin mendampinginya bersama-sama setia sampai mati tindakan tersebut merupakan sistem perekayasaan keseluruan tentang sikap dan perilaku seseorang serta cara berpikirnya (Wahid dkk., 2016). Seorang yang mengalami gejala psikopat itu sendiri selalu berpura-pura biasa dalam menyembunyikan tidakannya.

\section{Berperilaku Sadis}

Perilaku agresif pada seorang psikopat biasanya lebih dari perilaku agresif pada kebanyakan orang, seorang psikopat bisa saja tidak puas dengan serangan fisik atau verbal mereka biasanya akan puas ketika telah membunuh korbanya, seperti pada kitipan di bawah ini.

"Jadilah laki-laki maka kau harus membunuh. Jadilah laki-laki maka kau berhak merusak apa saja. Jadilah laki-laki maka dirimu akan kau rubah menjadi empat dinding penjara setebal satu kaki tanpa jendela. Jadilah laki-laki maka sebetulnya kau meriam siap ditembakkan! Dan malam itu sudah kunobatkan diriku sendiri jadi laki-laki. Laki-laki dengan naluri hewani yang dibiarkan lepas ikatannya" (Riantiarno, 1977).

Hal itu terjadi karena seorang psikopat memiliki emosi yang dangkal, mudah terpancing karena hal sepele, dan tidak dapat mengendalikan diri (impulsif), (Eva, 2011). Perilaku agresif dalam naskah drama "Cermin" terjadi pada tokoh utama, yaitu ketika tokoh utama membunuh 6 orang dan melukai 3 orang.

Faktor-Faktor Penyebab Tokoh Berperilaku Psikopat dalam Naskah Drama Cermin Karya Nano Riantirno 
Faktor yang menyebabkan seorang menjadi psikopat disebabkan oleh tiga faktor yaitu: faktor biologis, faktor lingkungan, dan faktor traumatis (Aksan, 2008: 65-66).

\section{Faktor Biologis}

Penyebab tokoh berperilaku psikopat secara faktor biologis disebabkan oleh kelainan genetis, dan adanya perubahan pada psikis kimiawi tubuh seperti ketakutan, rasa cemas, dan frustasi kepada seseorang. Semuan itu muncul karena adanya kegagalan dalam struktur kepribadian super-ego, pada kasus seorang psikopat, superego gagal dalam mengawasi atau menekan keinginan sempurna dari keinginan id yang di dominasi oleh ego, seperti pada kutipan berikut ini.

"Su, perempuan biasa. Tidak cantik tetapi punya daya tarik yang luar biasa, kegairahan hidupnya seperti kuda tak terkendali! Salahku memang, mengawini perempuan bekas pelacur. Padahal tadinya sudah kurelakan, dia bekerja, aku juga bekerja. Tapi Su selalu bilang padaku: ah, kamu tidak pernah bisa memberiku apa-apa selain anak. Ya, itu kenyataan. Dan karena itu pula dia berhak menutup mataku, mulutku dan menahan gerak semua anggota tubuhku. Tapi memang semua itu termasuk dalam perjanjian. Dan kami sudah saling menjanjikannya, dulu waktu dia kukawini. Kenyataan ini mampu kutahan sampai beberapa lamanya, 3 anak. Cuma itu katanya yang bisa kuberikan padanya, ya! Tapi lihat muka anak-anak itu satu persatu kalau mereka masih hidup. Lihat dengan teliti. Seperti siapa mereka? Adakah persamaannya denganku? Sama sekali tidak. Yang sulung entah seperti siapa? Yang kedua entah seperti siapa dan yang ketiga kulitnya hitam pekat dengan mata yang bulat dan rambut keriting kecil-kecil. Anakkukah itu? Anak Su! Aku pernah punya pikiran mungkinkah ada dokter-dokter jahil yang senang menukar-nukar bayi di RS bersalin, atau perawat-perawatnya. Tapi hal itu tidak mungkinkan? Mereka pasti menghormati sekali sumpah jabatan. Tapi aku bisa memastikan anak yang ketiga bukan anakku!" (Rianiarno, 1977).

Dari kutipan di atas seorang tokoh utama sudah mulai terkena gangguan psikisnya akibat frustasi kepada sang istri yang seorang pelacur yang hanya bisa memberikan anak saja, tetapi anak tersebut dari segi fisik berbeda-beda apalagi anak yang ketiga yang lebih cenderung seperti bukan darah dagingnya mengakibatkan tokoh utama memiliki super-ego.

\section{Faktor Lingkungan}

Faktor penyebab tokoh berperilaku psikopat secara lingkungan dikarenakan oleh pengaruh lingkungan di mana seseorang tumbuh dan dibesarkan. Pengaruh tersebut meliputi norma dalam keluarga, teman, kelompok sosial, dan pengaruh-pengaruh lain yang seorang dapat alami seperti pada kutipan di bawah ini.

"Kujelaskan lagi! Aku ingin janji kita dulu, kalau kau melakukan dengan orang-orang yang berbeda tanpa rasa apa-apa masih bisa kupikir-pikir. Tapi Su demi Tuhan jangan biasakan Cuma dengan satu orang. Su makin marah. Dia membayar dengan baik, katanya lalu pergi dengan membanting pintu. Tidak, kataku dalam hati. Mulutnya memang mengatakan itu, tapi kilatan matanya menceritakan pernyataan lain. Rasa panas dan dingin tiba-tiba menyatu dalam 
tubuhku. Aku juga berdiri seperti sekarang ini, menghadap ke satu arah dan melihat ..... kamu. Lalu pada malam harinya, malam kejadian yang luar biasa sepanjang sejarah hidupku....... Aku juga diam-diam seperti begini, memandang ke satu arah ke satu titik. Dibatasi oleh garis samar kita saling tatap. Niat yang sudah lama terpendam berkobar lagi tanpa mau mencegah. Lagi-lagi mencegah. Kau beritahu lagi tentang keselarasan susunan alam kita yang sudah diatur oleh Tuan berkerudung abu-abu yang tidak pernah bisa kulihat wajahnya itu. Tapi kamu tidak pernah mempelajari aliran air. Makin dibendung makin berusaha untuk menjebol" (Riantiarno,1977).

Tokoh yang berperilaku psikopat karena faktor lingkungan pada naskah drama "Cermin", yaitu tokoh utama. Hal itu disebabkan oleh lingkungan kelompok sosial yang keras. Tokoh utama sering berbicara sendiri dan menganggap sebuah cermin adalah temannya yang setia. Oleh karena hal tersebut tokoh utama mengalami tekanan dari lingkungan kelompok sosial.

\section{Faktor Traumatis}

Kata traumatis sendiri memiliki arti keadaan jiwa terguncang oleh suatu peristiwa di masa lalu, peristiwa tersebut memengaruhi psikis seseorang yang menimbulkan trauma atau prespektif lain yang berlainan dengan norma-norma atau aturan-aturan yang ada di masyarakat seperti pada kutipan berikut ini

"Aku ingat sekarang siapa kamu. Sehari sebelum kejadian itu, sesudah pertengkaran dengan Su. Kubujuk Su, tinggalkan $\mathrm{Su}$, hentikan semuanya. Su malah marah. Kita mesti hidup katanya. Apa tidak bisa hidup yang wajar, sederhana? kataku padanya. Su lebih marah lagi, matanya membelalak, kamu Cuma bisa melarang jangan begini jangan begitu tapi apa kamu pernah berpikir bagaimana caranya mengatasi kesulitan-kesulitan? Kujelaskan lagi! Aku ingin janji kita dulu, kalau kau melakukan dengan orang-orang yang berbeda tanpa rasa apa-apa masih bisa kupikir-pikir. Tapi Su demi Tuhan jangan biasakan Cuma dengan satu orang" (Rianiarno, 1977).

Dalam kutipan di atas seorang tokoh utama terkena faktor traumatis waktu sedang mengingatkan sang istri kala itu akan tetapi sang istri tidak menggubrisnya sama sekali akhirnya hal itu pun mejadi tekanan psikis tersendiri oleh seotang tokoh utama sebagai seorang suami.

\section{SIMPULAN}

Berdasarkan hasil penelitian dapat diketahui bahwa (1) bentuk perilaku psikopat yang terbagi ke dalam tiga bentuk, yaitu ringan, sedang, dan berat. Bentuk perilaku psikopat tersebut diketahui berdasarkan perilaku khusus pada seorang psikopat yaitu perilaku antisoasial, suka memanipulasi, dan berperilaku sadistis. (2) Faktor yang menyebabkan tokoh dalam naskah drama "Cermin" berperilaku psikopat, yaitu faktor biologis, faktor lingkungan, dan faktor traumatis.

Berdasarkan hasil penelitian, diharapkan penelitian ini dapat menjadi referensi bagi pembaca untuk menghasilkan karya-karya baru baik caranya, maupun medianya, terutama yang menggunakan teori psikologi sastra dan gangguan kepribadian psikopat. Perlu diadakan penelitian lanjutan yang lebih mendalam dengan kajian yang berbeda karena penelitian ini hanya berpusat pada fenomena perilaku psikopat berupa bentuk 
perilaku dan faktor penyebabnya. Masih banyak aspek lain yang belum pernah dikaji untuk menambah wawasan atau pengetahuan dalan studi susastra.

\section{DAFTAR PUSTAKA}

Aksan, H. (2008). Jejak pembunuh berantai: Kasus-kasus pembunuhan berantai di Indonesia dan dunia. Jakarta: PT Grafindo Media Pratama.

Andalas, E. F. (2017). Eskapisme realitas dalam dualisme dunia alice: Telaah psikologisastra film Alice in Wonderland (2010). KEMBARA: Jurnal Keilmuan Bahasa, Sastra, dan Pengajarannya, 3(2), 185-195.

Anwar, F. (2018). Kritik Sosial dalam naskah drama alangkah lucunya negeri ini karya Deddy Mizwar. Bahasa dan Sastra, 4(1).

Eva, Z. F. (2011). Representasi perilaku psikopat dalam film "Fiksi" (Studi analisis semiotik terhadap film "fiksi" karya Mouly Surya) (Doctoral dissertation, UPN "Veteran" Jawa Timur).

Fathoni, F. R., \& Imam, M. (2020). Analisis tokoh Khamid dalam naskah Pasung karya Dwi Mustanto (Analisis teori psikoanalisa Sigmund Freud) (Doctoral dissertation, IAIN Surakarta).

Ghozali, I. (2016). Aplikasi Analisis Multivariate dengan Program IBM SPSS 2. Semarang: Universitas Diponegoro Tumpang.

Mulyadi, M. (2011). Penelitian kuantitatif dan kualitatif serta pemikiran dasar menggabungkannya. Jurnal Studi Komunikasi dan Media, 15(1), 128-137.

Riantiarno, N. (1977). CERMIN. Cirebon: The Jakatra Post.

Rozali, R. (2018). Fenomena perilaku psikopat dalam novel Katarsis karya Anastasia Aemilia: Kajian psikologi sastra. Jurnal Sastra Indonesia, 7(3), 173-178.

Santoso, M. B., Krisnani, H., \& Deraputri, G. N. I. (2017). Gangguan kepribadian antisosial pada narapidana. Share: Social Work Journal, 7(2), 18-27.

Wahid, R. N. N., Thoyibi, M., Fatimah, S. (2016). The Psychopath Phenomenon Reflected in Gillian Flynn'S Gone Girl Novel (2012): A Psychoanalytic Approach (Doctoral dissertation, Universitas Muhammadiyah Surakarta).

Zahidi, M. K. (2019, November). Perlawanan perempuan dalam antologi puisi Koleksiku karya Joko Pinurbo. In Prosiding Seminar Nasional Bahasa dan Sastra Indonesia (SENASBASA) (Vol. 3, No. 2). 